showed a satisfactory response to HCG. Whether this occurred as a compensatory adjustment of the "gonadostat" necessary for maintaining adequate testosterone secretion or as a nonspecific effect of the prevailing general conditions on pituitary gonadotrophic function remains a matter of speculation.

Low basal and post-HCG testosterone concentrations and a subnormal response to HCG, particularly in the late recovery phase, indicated that impairment of Leydig-cell function may have occurred in several patients as a result of mumps orchitis. The condition probably develops as a long-term effect of the disease, leading to permanent damage of the Leydig cells similar in importance to that of the germinal epithelium.

Satisfactory post-HCG testosterone and basal FSH concentrations were found in patients with acute unilateral orchitis and those treated with cold baths. Probably in patients with unilateral disease a large proportion of the Leydig-cell population, notably that of the unaffected testis, functioned properly to sustain testosterone secretion within the normal range. Cold bathing may also have had some protective effect, though no firm conclusion on its efficacy as a therapeutic regimen could be drawn.

Though we expected the plasma FSH concentration to be increased in patients with mumps orchitis, we were surprised that it occurred at such an early stage. After recovery the FSH concentrations, and LH concentrations, remained high in some patients.

Our findings show that mumps orchitis has a deleterious effect on Leydig cells in the acute phase of the disease and may result in permanent impairment of their secretory activity. The long-held view that Leydig-cell function is preserved more or less intact after recovery from mumps orchitis should therefore be reconsidered.

We express our gratitude to the patients and healthy subjects who participated in this study. The work was partly supported by a grant from "Empirikeion Foundation" to DAA. LH-RH was donated by Hoechst AG.

Requests for reprints should be sent to DAA.

\section{References}

${ }^{1}$ Marcy, S X, and Kibrick, S, Infectious Diseases, p 657. New York, Harper and Row, 1972.

2 Top, F H, and Wehrle, P F, Communicable and Infectious Diseases, p 427. St Louis, C V Mosby, 1972.

3 Turner, J H, and Bloodworth, J M B, Endocrine Pathology, ed J M B Bloodworth, p 430. Baltimore, Williams and Wilkins, 1968.

+ Adamopoulos, D A, et al, Acta Endocrinologica (Kфbenhavn), 1975, 199, suppl, p 416 (abstract).

5 Castro, A, Shih, H H W, and Chung, A, Steroids, 1974, 23, 625.

${ }_{6}$ Dunnett, C W, American Statistical Association fournal, 1955, 50, 1096

Sowers, R A J, jun, et al, Acta Endocrinologica (Kфbenhavn), 1977, 86, 25.

"Aono, T, et al, fournal of Clinical Endocrinology and Metabolism, 1976, 42, 144.

9 Paulsen, C A, et al, Recent Progress in Hormone Research, 1968, 24, 321.

10 Adamopoulos, D A, et al, fournal of Reproduction and Fertility, 1971, 25, 409.

(Accepted 27 February 1978)

\title{
Underlying immunopathology as a cause of adverse responses to two intravenous anaesthetic agents
}

\author{
JOHN WATKINS, ADRIAN PADFIELD, J D ALDERSON
}

British Medical fournal, 1978, 1, 1180-1181

\section{Summary and conclusions}

A patient who had shown some evidence of immunological sensitivity underwent several operations under general anaesthesia for otitis media without ill effect. On his second exposure to Althesin, however, he suffered a severe reaction. Facial angioneurotic oedema was accompanied by peripheral vasodilatation and sweating, and C3 conversion was observed in his plasma. Subsequent anaesthetics produced no reactions until four years later, when thiopentone and suxamethonium were given. This reaction was much milder, but $\mathrm{C} 3$ conversion again occurred. Although the clinical signs indicated an anaphylactoid reaction, the laboratory findings suggested that this patient had an underlying immunopathological condition involving complement activation, which could be triggered by any intravenous agent that activated complement.

The judgment that a reaction to a particular drug is

\footnotetext{
University of Sheffield Medical School, Hallamshire Hospital, Sheffield S10 2RX

JOHN WATKINS, PHD, principal scientific officer, department of immunology

ADRIAN PADFIELD, MB, FFARCS, consultant anaesthetist

J D ALDERSON, MB, FFARCS(I), senior registrar in anaesthetics
}

anaphylactic cannot be made on the basis of clinical signs alone. Simple laboratory analysis will show whether the reaction is due to an underlying immunopathological condition that may be triggered by any of several drugs.

\section{Introduction}

There is now considerable interest in the incidence and mechanism of adverse responses (either histaminoid or anaphylactoid) to intravenous agents. We describe here a patient who responded adversely to two intravenous anaesthetic agents which were administered on separate occasions for identical operations.

\section{Case report}

A 21-year-old student had suffered from otitis media since infancy, for which he had undergone several operations under genera anaesthesia over the past 12 years (table I). He showed some evidence of immunological hypersensitivity in that he had developed eczema in infancy and was noted by his parents to be sensitive to orange juice, which gave him swollen lips. Skin tests were unable to confirm this allergy to orange juice.

His first exposure to Althesin (alphaxalone and alphadolone acetate), in 1973, was uneventful, but his second, for an identical procedure about 18 months later, produced dramatic effects. Anaesthesia was induced intravenously with $4.5 \mathrm{ml}$ of Althesin, and three minutes later angioneurotic oedema developed around the lips and spread across the face. This was accompanied by peripheral vasodilatation and sweating. There was no bronchospasm, dyspnoea, or cyanosis but the pulse 
TABLE I-Anaesthetic history

\begin{tabular}{|c|c|c|c|}
\hline Date & Procedure & Anaesthetic & Reaction \\
\hline March 1966 & Cautery of nose & $\begin{array}{l}\text { General anaesthetic, } \\
\text { type unknown }\end{array}$ & None \\
\hline Feb 1973 & $\begin{array}{c}\text { Myringotomy and } \\
\text { grommets }\end{array}$ & $\begin{array}{l}\text { General anaesthetic, } \\
\text { type unknown }\end{array}$ & None \\
\hline May 1973 & " & Althesin, & None \\
\hline Oct 1974 & Incomplete & $\begin{array}{l}\text { Althesin, } \\
\text { N.O O, -halothane }\end{array}$ & Anaphylactoid \\
\hline Dec 1974 & $\begin{array}{l}\text { Myringotomy and } \\
\text { grommets }\end{array}$ & $\begin{array}{l}\text { Methohexitone, } \\
\mathrm{N} \mathrm{O} \text { O -halothane }\end{array}$ & $\begin{array}{l}\text { None } \\
\text { None }\end{array}$ \\
\hline Oct 1975 & " & $\begin{array}{l}\text { Methohexitone, } \\
\mathrm{N} \mathrm{O} \text { O -halothane }\end{array}$ & None \\
\hline Jan 1978 & " & $\begin{array}{l}\text { Thiopentone, } \\
\text { suxamethonium, } \\
\mathrm{N}_{2} \mathrm{O} \mathrm{O}_{2} \text {-halothane }\end{array}$ & Lip swelling \\
\hline
\end{tabular}

became weak and rapid and the systolic blood pressure fell to $50 \mathrm{~mm}$ $\mathrm{Hg}$. After oxygen, intravenous chlorpheniramine $10 \mathrm{mg}$, and hydrocortisone $100 \mathrm{mg}$ had been given his systolic blood pressure rose steadily and he slowly recovered consciousness. Angioneurotic oedema persisted for 24 hours. Skin tests showed no allergy to Althesin, though plasma studies suggested transient variations in IgE concentrations. Considerable C3 conversion, consistent with the degree of tissue oedema, was observed in his plasma (table II).

Anaesthetics were subsequently administered with no ill effects until January 1978, when the patient's upper lip began to swell considerably after administration of thiopentone $350 \mathrm{mg}$, suxamethonium $75 \mathrm{mg}$, and maintenance with an $\mathrm{N}_{2} \mathrm{O} / \mathrm{O}_{2} /$-halothane, mixture. There was no evidence of cardiovascular instability, bronchospasm, or other signs of a serious reaction, and the swelling regressed spontaneously after several hours. Nevertheless, laboratory analysis again showed C3 conversion in the patient's plasma immediately after operation. This, in contrast to the 1974 reaction, cleared rapidly.

\section{Discussion}

The laboratory findings at the time of the first reaction suggested an underlying immunopathological condition involving complement utilisation. This might have been an immune reaction to chronic infection. We have suggested that such conditions predispose towards C3 alternate pathway activation, particularly with drugs such as Althesin. ${ }^{12}$ There was no evidence of an immune mediated response to the Althesin. Although the 1978 reaction was clinically trivial, C3 activation again occurred. So far as our records show, this was the first time that either thiopentone or suxamethonium had been given to the patient, so an immune-mediated reaction is unlikely. Although we have seen some complement-mediated reactions to thiopentone it is an unusual feature of thiopentone, ${ }^{12}$ and the patient may have reacted to suxamethonium or perhaps to the combination of the drugs.

We suggest that the curious mixture of allergic and chronic infection or secretion states in this patient made him intermittently highly susceptible to certain intravenous agents known to activate complement. We think that this case underlines a fallacy in the general interpretation of the adverse response to intravenous agents. These reactions are often described as "anaphylactoid," a term that is widely used to describe clinical manifestations (cutaneous, pulmonary, and cardiovascular) that resemble those of antibody (reagin)-mediated histamine release from mast cells. Although a reaction may be a true anaphylactic response, this assumption cannot be made on the basis of the clinical manifestations alone. We have previously emphasised the importance of simple laboratory tests to evaluate such reactions. ${ }^{1-3}$ If these are not carried out then the patient may be warned that he is allergic to a particular drug and that this is not to be used again. Although this advice is basically sound, it ignores the fact that the patient may not have reacted directly to the drug. Instead the reaction may have been a non-specific effect triggered by any drug that exacerbated an underlying primary (genetic) or secondary (induced) immunopathological condition. This may explain why such a patient later reacts adversely to a totally different drug from that which was implicated in the first reaction.

\section{References}

1 Watkins, J, et al, British Fournal of Anaesthesia, 1976, 48, 457.

2 Watkins, J, Ward, A M, and Appleyard, T N, British Medical fournal, 1977, 2, 1084.

${ }^{3}$ Watkins, J, et al, British fournal of Anaesthesia, 1976, 48, 881.

(Accepted 23 February 1978)

TABLE II-Plasma chemistry at time of adverse response

\begin{tabular}{|c|c|c|c|c|c|c|c|c|}
\hline Incident & $\underset{(\mathrm{g} / 1)}{\mathrm{IgG}}$ & $\begin{array}{l}\mathrm{IgA} \\
(\mathrm{g} / \mathrm{l})\end{array}$ & $\underset{(\mathrm{g} / 1)}{\operatorname{IgM}}$ & $\underset{(I U / m l)}{\operatorname{IgE}}$ & $\begin{array}{c}\text { C3 } \\
(\mathbf{g} / 1)\end{array}$ & $\underset{(\mathrm{g} / \mathrm{l})}{\mathrm{C} 4}$ & $\underset{(\mathrm{g} / \mathrm{l})}{\mathrm{C} 1} \underset{\text { inhibitor }}{ }$ & C3 conversion \\
\hline $\begin{array}{l}\text { Anaphylactoid response Oct } 1974 \\
\text { Lip swelling Jan } 1978\end{array}$ & $\begin{array}{l}10 \cdot 1 \\
10 \cdot 6\end{array}$ & $\begin{array}{l}2 \cdot 6 \\
2 \cdot 6\end{array}$ & $\begin{array}{l}0.6 \\
0 \cdot 2\end{array}$ & $\begin{array}{r}260 \\
18\end{array}$ & $\begin{array}{l}0 \cdot 42 \\
1 \cdot 10\end{array}$ & $\begin{array}{l}0 \cdot 12 \\
0.35\end{array}$ & $\begin{array}{l}0 \cdot 20 \\
0 \cdot 38\end{array}$ & $\begin{array}{l}\geq 50 \\
\leqslant 30\end{array}$ \\
\hline
\end{tabular}

\section{SIDE EFFECTS OF DRUGS}

\section{Production of ischaemic cardiac pain by nifedipine}

Nifedipine (Adalat) is recommended for the treatment and prophylaxis of angina. Side effects are claimed to be rare, but transient headache, facial flushing, and dizziness may occur on starting treatment. We describe three patients treated with nifedipine in whom these side effects were accompanied by severe chest pain simulating a myocardial infarction or severe angina. This has not been described.

\section{Case reports}

Case 1-A 57-year-old woman had a myocardial infarction in 1965 with subsequent typical effort angina. Metroprolol reduced the frequency of anginal episodes but caused weakness and was discontinued. One hour after receiving nifedipine $10 \mathrm{mg}$ she had facial flushing, nausea, and severe precordial pain lasting for 30 minutes. She compared these symptoms to those accompanying her previous myocardial infarction. There was no appreciable change in pulse, blood pressure, or electrocardiogram. She felt unwell for three hours. The drug was not readministered.

Case 2-A 50-year-old man had bronchial asthma and angina. About 30 minutes after the first dose of nifedipine $10 \mathrm{mg}$, he described agonising typical ischaemic chest pain lasting an hour. This sequence occurred on two further occasions when he took nifedipine, and he consequently abandoned its use. An electrocardiogram one week later showed no fresh abnormalities.

Case 3-A 71-year-old woman with maturity onset diabetes mellitus, psoriasis, and angina was given nifedipine $10 \mathrm{mg}$. Thirty minutes after the first administration she became sweaty with facial flushing followed by severe retrosternal chest pain lasting for two hours. There was no change in pulse, blood pressure, or electrocardiogram. The drug was discontinued.

\section{Comment}

In two recent studies, ${ }^{12}$ which covered 31 patients, nifedipine produced no serious side effects. Our patients described facial flushing 